\title{
Stop losing sleep over sleep
}

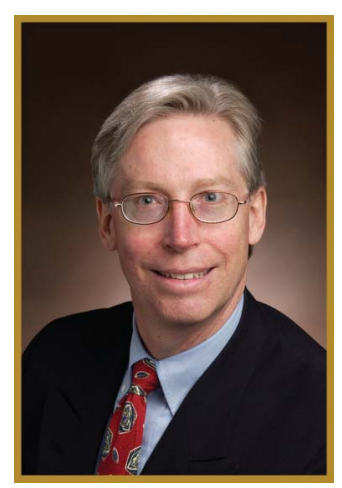

$\mathrm{F}$ or something that has a profound effect on physical health and mental wellbeing and that we spend up to a third or more of our lives doing, sleep remains a mystery to many physicians, neurologists included. Under the excellent direction of Alon Avidan, Neurology ${ }^{\circledR}$ Clinical Practice addresses these limitations with a series of articles on many facets of sleep disruption in both children and adults. Our goal is to provide practicing neurologists with meaningful assistance when confronting challenging sleep issues in their patients.

Sleep disorders are frequent comorbidities in neurologic patients and may portend future neurologic disease. Horowitz and Hungs describe sleep tests and provide a useful algorithm to guide the practicing neurologist's approach to evaluation. As parents know, sleep plays a major role in raising a happy, well-adjusted child. Felt and Chervin recommend a multifactorial approach to sleep disorders in children that includes behavioral strategies and medications available for use in this age group. Sleep-disordered breathing (SBD) is associated with a growing list of neurologic conditions. An article by Salas et al. provides the latest information on SDB and offers advice for management of sleep apnea in the neurology patient. Erik St. Louis provides an overview of key sleep neurologic disorders, and Molano and Vaughn explore challenges and considerations related to insomnia in a patient with dementia. Evaluation and management of sleep disorders is closely monitored by government and private insurers. Raphaelson and Brown offer advice to the practicing neurologist to keep pace with changing policies and overcome administrative obstacles.

As always, we invite your participation as an author, reviewer, or respondent via our correspondence section, The Nerve!
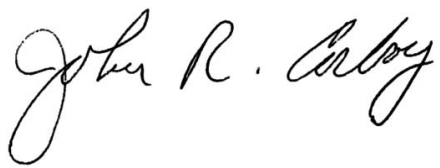

John R. Corboy, MD, FAAN 


\section{Neurology ${ }^{\circ}$ Clinical Practice}

Stop losing sleep over sleep

Neurol Clin Pract 2014;4;1

DOI 10.1212/01.CPJ.0000442715.53060.42

This information is current as of February 17, 2014

\section{Updated Information \&}

Services

Permissions \& Licensing

Reprints including high resolution figures, can be found at:

http://cp.neurology.org/content/4/1/1.full.html

Information about reproducing this article in parts (figures,tables) or in its entirety can be found online at:

http://cp.neurology.org/misc/about.xhtml\#permissions

Information about ordering reprints can be found online:

http://cp.neurology.org/misc/addir.xhtml\#reprintsus

Neurol Clin Pract is an official journal of the American Academy of Neurology. Published continuously since 2011, it is now a bimonthly with 6 issues per year. Copyright ( 2014 American Academy of Neurology. All rights reserved. Print ISSN: 2163-0402. Online ISSN: 2163-0933.

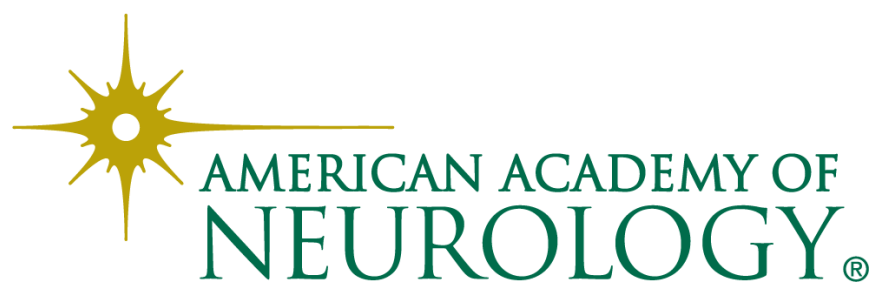

